\title{
The Variety of Davids in Monotheistic Traditions
}

\author{
An Introduction
}

\author{
Marzena Zawanowska
}

One of the most central figures in all of the major monotheistic traditions is King David. He personifies, in many respects, the heroic past of the (more imagined than real) ancient Israelite empire, of which he is commonly believed to have served as a unifying and effective king for about forty years (ca. 1010-970 BCE). David's religious persona as a righteous king is underlined in the Hebrew Bible and in the New Testament, where he is hyperbolically described as a man after God's own heart (1 Samuel 13:14; Acts 13:22), while in the Qurān he is depicted as God's "vicegerent on earth" (Sura 38:26). His prophetic abilities are also elaborated in the Hebrew Bible through God's various revelations to him and prophecies conveyed through him, while his righteousness is underscored in the Psalms attributed to him, which led to his subsequent recognition as a prophet in Islam.

In religious imagination, as well as in wider culture, literature and the arts, the figure of David has not only come to symbolize the golden period in the remote past of the ancient Kingdom of Judah and Israel of the first millennium BCE, but also as a source of revival and messianic hopes for the future, as in the famous biblical metaphor "a shoot from the stump of Jesse" (Isaiah 11:1-12). From post-exilic times, Jews believed that the messianic savior-king who will usher in an era of eternal peace and prosperity was to come from Davidic lineage, and it is in this light that the early Christians conceived his connection to Jesus which they made clear in two of the Gospels (Matthew 1; Luke 3:23-38).

While the reception exegesis in all three religious traditions generally tended to idealize his image, David's literary portrayal in the Hebrew Bible is one of the most complex of all biblical characters. On the one hand, he is depicted as a valorous warrior who bravely defeated Goliath (1 Samuel 17:49-50), the powerful army commander and ruler responsible for unifying a kingdom around the Jebusite city, Jerusalem, which he conquered and then established as capital, a gifted musician (1 Samuel 16:14-22), who by himself invented musical instruments (Amos 6:5; 1 Chronicles 23:2-5), a pious poet who authored some of the psalms contained in the Book of Psalms (generally attributed to his authorship in later sources), an affectionate lover (e.g., of Abigail in 1 Samuel 25), and a devoted friend (e.g., of Jonathan in 1 Samuel 13-23) and father (cf. his mourning over Absalom's death in 2 Samuel 18:33). On the other hand, he 
is described as a vassal of the Philistine king Achish of Gath (1 Samuel 27), a ruthless politician, who ended the dynasty of Saul through acts of murder and force (2 Samuel 1-10), and someone who committed adultery with a married woman, Bathsheba, and eventually conspired to murder her husband, Uriah, one of his chief warriors (2 Samuel 11-12). For having "shed much blood" (1 Chronicles 22:8-10) and his infamous love affair, he is strongly criticized in the Bible itself (2 Samuel 12). By divine decree, and as a result of his morally dubious behavior, his offspring fall into calamity, culminating in the rebellion and subsequent killing of his beloved son Absalom (2 Samuel 11-1 Kings 2) and God defers the building of the Temple to the time of his son from Bathsheba, Solomon (2 Samuel 7; 1 Kings 8; 1 Chronicles 17:4; 2 Chronicles 6:9). Little wonder, therefore, that David's richly ambivalent and fascinating biblical portrayal engendered varied interpretative traditions and that his character consequently underwent significant transformations in perception and reception in the three monotheistic traditions.

For many centuries, one of the most dominant and common modes through which the story of David was addressed was the translation and commentary of the sanctified texts. Yet there were also other important forms of composition (such as legends, liturgical poems, homilies etc.) which developed alongside this traditional form of religious expression and which not infrequently elaborated on the Davidic narratives. Consequently, there existed in the pre-modern period a range of literary works which were used as a framework for intellectual reflections on David and his attributed book of Psalms, ranging from geographic, historical, and grammatical, through pietistic, ethical and heresiographical, to mystical, philosophical and/or theological. In the modern period, the popular genre of biblical translation and exegesis was used alongside secular literature and art in addressing King David. The present volume is devoted, in the main, to the pre-modern understanding and interpretation of David in the three monotheistic religions, as reflected in the translations and commentaries on the Scriptures written by Jews, Christians and Muslims. Nevertheless, papers devoted to selected works belonging to other genres of their respective religious (and to a lesser extent non-religious) literature are also included.

The most fervent exegetical activity took place in the Middle Ages, the period when Judaism, Christianity and Islam consolidated their respective religious traditions, by creating or reshaping them in constant conversation with and (often polemical, or apologetic) response to one another. After the canon of the Hebrew Bible had been sealed, sometime around the mid second century $\mathrm{CE}$, Jews, later joined by Christians, engaged in interpretative processes not only to establish its inherent meaning but also, and more importantly, 
its meaning within a given religious community. Muslims, too, became part of this process due to the Prophet Muhammad's essential verification of the divine message contained in the Scriptures of the "People of the Book" (Ar. ahl $a l-k i t \bar{a} b$ ) and the acceptance of their Prophets as God's chosen messengers in the Qurān. Thus the three groups needed to position themselves vis-à-vis the others, with whom they shared a belief in the revelatory nature of some (if not all) of the Scriptures. In this sense, the medieval period, ranging from the rise of Islam to the High Middle Ages (around the eighth to the twelfth centuries CE) constituted a mosaic of different monotheistic traditions and their intellectual legacies, and was characterized by intensive, cross-fertilizing contacts as well as cross-cultural transfers of concepts and ideas between Judaism, Christianity and Islam. This was the most important period in the theological crystallization of the three religions, all of which were engaged in defining their cultural and religious identities vis-à-vis the other. It is likely that the common core of these three religions, as we know them today, gained many of its distinctive traits during this period, through a complex process of "dialogue," by which is meant mutual interchanges and subsequent transformations of textual traditions, including their appropriation to their own specific cultural and intellectual contexts, as well as their considerable propensity for strife and conflict.

The wide array of exegetical techniques elaborated during the medieval period includes: Jewish, midrashic atomizing and homiletical gap-filling methods; allegorical and analogical readings typical of Christian exegesis; grammatical, literary-contextual and historical approaches, which significantly developed in the realm of Islam. These systems eventually overlapped in their usage and cross-fertilized each other, and the specific explanations they offered in resolving scriptural conundrums and interpretative cruxes became fundamental to many later approaches to reading and studying the sacred texts. They also informed later interpretative methods, including modern secular ones.

The main focus of the present volume is therefore on the Middle Ages, although articles exploring works composed in other periods are also included as comparative sources, in an attempt to trace the development of chains of interpretive traditions, as well as the evolution and transformation of exegetical ideas. An additional reason for focusing on the medieval period is that it witnessed a conspicuous rise in popularity of the biblical figure of King David and his post-biblical lineage. Jewish and Christian traditions, prior to the emergence of Islam, exhibited a concern with the House of David but it is only after the emergence of Islam in the seventh century $\mathrm{CE}$ that a gradual growth of the spiritual importance of his family, as well as of the social-administrative status of its members may be observed in Jewish and Christian sources. The concern 
with Davidic ancestry is borne out by the fact that the number of individuals claiming to be either direct (Heb. nésiīm), or at least spiritual (Byzantine, Carolingian and Capetian kings) descendants of King David noticeably increased, and that for the first time in history pedigrees tracing medieval dynasties back to their alleged Israelite forebear were produced. ${ }^{1}$ Also, the new and unmistakable preference for the name David, until then avoided and (with only few doubtful exceptions) completely absent from earlier epigraphic, literary, and documentary sources, suddenly emerged sometime in the eighth century, in the Islamic realm. ${ }^{2}$

Finally, the Middle Ages witnessed an unusual degree of spiritual unrest, especially in the Middle East, which brought about not only the emergence of new religions like Islam and other religious movements and sects, described in medieval heresiography, but also major divisions within existing religions such as the split between the adherents of Sunnism and Shicism within the Muslim world, or between the Rabbanites and Karaites within the Jewish world. The example of Karaism is particularly important in the context of the present volume since it seems to have emerged as the result of the Jews' encounter with the Islamic scriptural model. ${ }^{3}$ The Karaites' rejection of the rabbinic concept of the "Oral Torah" and the post-biblical texts in which it was incorporated (mainly the Mishnah and Talmuds) seems to be connected to the medieval Jews' need to authenticate the Hebrew Bible vis-à-vis the Qur'ān. At least at the initial stage of its development, Karaism was a conglomerate movement, which combined representatives of the Jewish (gaonic) elite alongside marginalized Jewish sectors and members of various heterodox groups and, consequently, it played an important role in cross-cultural interchanges with Christians and Muslims. ${ }^{4}$ As such it constitutes a salient case study for exploring cross-cultural interchanges among different monotheistic traditions, especially in the Middle Ages.

1 See Franklin, This Noble House.

2 See Moss, From David to Davids.

3 See Polliack, "Conceptualization"; eadem, "The Karaite Inversion." Cf. Ben-Shammai, "The Karaite Controversy"; idem, "Return to Scriptures"; Cook, "Anan and Islam."

4 On the origins of the Karaite movement, see Gil, "Karaite Antiquites"; idem, "The Origins." For studies of Karaite perspective, see Astren, Karaite Judaism; Akhiezer, Historical Consciousness. On the Karaites as playing an important role in cross-cultural interchanges with Christians and Muslims, see Drory, The Emergence. 
The present volume aims at taking a new, critical look at the process of biblical creation and subsequent exegetical transformation of the character of David and his attributed literary composition, with particular emphasis put on the multilateral fertilization and cross-cultural interchanges among Jews, Christians and Muslims. To this end it brings together scholars from various research disciplines (such as literary, linguistic, cultural and religious studies) related to Jewish, Christian and Islamic studies, who critically examine different source texts related to King David and the book of Psalms. Thanks to this, the volume encompasses a detailed and comparative view of converging and diverging tendencies in the way David, his character and narratives on his life, as well as his attributed book were reclaimed, and fashioned in these religious cultures. It includes papers whose authors not only investigate transformations of the biblical materials in one given religious tradition, but also - and above all - in the intertwined worlds of the three major monotheistic cultures in cross-fertilizing contact. Therefore, in addition to monographic chapters devoted to the reception of David and the Psalter in individual religious movements and cultures (e.g., Ethiopian Christianity, Carolingian and Capetian empire, or Frankism), a significant number of articles utilise a comparative approach, scrutinizing the various texts in which David's character and his attributed book have been appropriated and re-positioned in different traditions of the so-called "People of the Book" from biblical times and late antiquity until the early modern period. The twenty two chapters of the book are divided into four coherent thematic sections which focus on different aspects of the reception history of David and the Psalms in monotheistic traditions. As far as it was possible, individual chapters within each section were ordered chronologically.

\section{Structure}

Everything begins with the Hebrew Bible, the chief (if not unique) textual evidence on the historical King David, which served as an inexhaustible source of inspiration for later literature, especially of an exegetical nature, composed in different times and places by representatives of different religious traditions. Therefore the opening chapter, contributed by Łukasz Niesiołowski-Spanò, David in History and in the Hebrew Bible, is devoted to an historical survey of this scriptural character, offering a rich review of various scholarly approaches to the intricate and much debated question of David's historicity. It explores the complex relationship between the biblical and extra-biblical evidence for David, discussing inter alia the etymology of the name David, the reliability 
of extra-biblical testimonies (inscriptions) to the House of David, as well as historical context and circumstances in which the biblical character was supposedly active. It conjectures that, assuming the historicity of this figure, David might have been a local leader of a small, Habiru-like group active in the tenth century BCE in the Southern territories dominated by the Tribe of Benjamin and politically controlled by the Philistines from the City of Gath.

\subsection{The Images of David in Medieval Jewish, Muslim and Christian Sources}

The first chapter in this section focuses on 1 Samuel 16:14-22, where David is depicted as an accomplished musician and 1 Chronicles $23: 2-5$, where he is credited with the invention of musical instruments. Due to his centrality to all Abrahamic religions, medieval sources, both Jewish and Muslim, had to consider how to address David's proclivity for music in a manner that would suit their different religious traditions, communities and views on music. In the paper David the Pious Musician in Midrashic Literature and Medieval Muslim Sources, Sivan Nir explores different ways in which Judaism and Islam treated the subject, highlighting their mutual interdependence as well as originality in this respect. It shows that the Talmuds, Ruth Rabbah and Midrash on Psalms depict David as a musician turned nightly scholar, and investigates how the midrashic imagery informed medieval Jewish commentaries on Psalms 107108 , as well as how it influenced portrayals of David's piety in Islam and the depictions of his musical skills (used against the demons) in various classical Muslim sources.

In the next chapter of this section, The Weeping King of Muslim Pietistic Tradition: David in the Kitāb al-wara' of 'Abd al-Malik b. Habīb (d. 238/853) and in Earlier Islamic Sources, Mateusz Wilk discusses the image of king David $(D \bar{a} w \bar{u} d)$ in the traditions contained in the Kitāb al-warac, a compilation of Islamic piety - more specifically, religious scrupulosity - by 'Abd al-Malik b. Habīb (d. 238/853), against the backdrop of earlier and contemporary Muslim literature. He argues that this hitherto unpublished work contains numerous traditions on prophets, yet David is the only one to whom a separate chapter is dedicated. The article presents and analyzes the role of David in the paradigm of Islamic piety of the third/ninth century through comparisons of Kitāb al-wara' with other similar sources from this period (e.g., Ibn Hanbal's Kitāb $a l$-zuhd). By doing so, it serves a starting point for further investigation of the role of prophets in the classical Islamic pietistic literature.

The following article by Yair Zoran, David and the Temple of Solomon in Medieval Karaite Sources. The Arabic Commentaries of Yefet ben 'Eli on the Books 
of Kings and Chronicles, delves more deeply into the subject of the medieval Karaite tradition of interpreting the Hebrew Bible, a tradition which exerted significant influence on later Jewish exegesis of Scripture as a whole. One of its most important and influential representatives was Yefet ben 'Eli who lived in the second half of the tenth and the beginning of the eleventh century, mostly in Jerusalem. He was the first to compose a comprehensive commentary, including running Arabic translation, on the entire Hebrew Bible. The article explores his treatment of David's testament to Solomon in 1 Chronicles 28 which relates to the building of the Temple, demonstrating the exegete's literary sensibilities, as well as his ingenuity and originality in the artful way in which he combines different biblical passages and weaves them together into a unified literary structure that sheds a new light on the interpreted text.

King David was a central figure not only in medieval exegetical and pietistic texts, but also in poetry. Our next author, Barbara Gryczan, contributes a paper David as Warrior, Leader, and Poet in Medieval Hebrew Poetry of al-Andalus: Shmuel ha-Nagid's Self-Portrait as "The David of His Age," in which she provides a detailed analysis of an autobiographical poem, Back away from me now, my friend, composed as a commemoration of Shmuel ha-Nagid's victory over the troops attacking the foregrounds of Granada. During the battle, he served as the-commander-in-chief of the army of the Berber king of this city-state. The article explores the process of artistic auto-creation, unravelling the complex matrix of biblical intertexts and historical allusions as well as artistic devices and poetical mechanisms introduced by the poet in order to portray himself not only as a righteous leader of the nation and a direct heir of the Levites, but also a divinely inspired poet, an anointed "singer of God," and "the David of his age." It also offers a commentary on the cultural and socio-historical background of ha-Nagid's times, as well as specific biographical insights, which put the examined poem in the broader context of the author's various activities as poet, scholar, soldier and community leader.

In the following article, David in MedievalJewish Thought.Judah Halevi's Book of the Kuzari as a Reconciliation Project, Marzena Zawanowska investigates the way in which the character of David was used in a philosophical-theological text written by one of the most famous medieval Jewish poets, Judah Halevi. She demonstrates how the author of the Kuzari de-biblicized the biblical character of David, using his idealized image as an instrument to convey and underscore what he considered the chief values and most important legacy of Judaism, namely: the Hebrew Bible (David as one of its authors); the Hebrew language (David as the author of the Psalms); the Chosen People with their unique gift of prophecy (David as a prophet); the Land of Israel with the 
Temple in Jerusalem as its "holy of holies" (David as responsible not only for providing the plans of the Temple, but also for establishing the cultic ritual in it). Zawanowska argues that the figure of David served Halevi as a vehicle to transmit his constructive critique of his present day Jewry, aimed at healing or repairing and improving the entire Jewish nation - in terms of both Rabbanites and Karaites alike - and bringing about their re-unification, thereby restoring Judaism to its former glory.

The next author, Jerzy Pysiak, brings us to the medieval Kingdom of France, showing how the late thirteenth and early fourteenth century French chroniclers and hagiographers fashioned Saint Louis's image after the model of biblical King David, as the pious and godly king of a New Israel - France. In his Saint Louis as a New David and Paris as a New Jerusalem in Medieval French Hagiographic Literature, he demonstrates that the development of this royal ideology was closely connected with the cult of saints and relics, and especially with the translation of Passion relics which, already in the Byzantine empire, was believed to have been tantamount to the translation of Jerusalem to a new location - the Christian capital city of Constantinople in that case. Exploring the complex history of the origins of the royal ideology of the Capetian kings, the paper argues that although it undoubtedly echoes the Byzantine imperial ideology, it evolved independently and its origins should be sought more accurately in the Carolingian epoch, in which - starting from the time of the anointing of Pepin the Short, David had become an ideal model for the kings of the Franks.

In the last chapter of this section, Ruth Mazo Karras focuses on Latin Christian literature. In her David and Jonathan as a Paradigm of Male Friendship in Medieval Latin Literature, she uses the story of David and Jonathan to examine how Christian and Jewish traditions in the Middle Ages treated friendship between men in relation to marriage between men and women. It demonstrates that David and Jonathan's friendship was most often invoked in the Christian Central Middle Ages in a monastic context, but also outside it. The deep and intimate love between two men could parallel that which would be found in a marriage, or even go beyond it. It argues that discussions of friendship in the Jewish tradition often occur in commentaries on Pirqe Avot. Male friendship is seen in this treatise in two ways: in terms of (1) companionship and partnership in Torah study, and (2) a relationship between David and Jonathan, which is on a spiritual level. This second kind of male friendship is contrasted with love between men and women. Karras concludes that the common denominator between both traditions is that the line between friendship and love is not sharp. 


\subsection{The Psalter of David in Monotheistic Traditions}

In contrast with mutual influences between medieval Jewish and Muslim cultures and literatures, relatively little attention has so far been paid to Jewish Christian cross-cultural interchanges in the Middle Ages. In his paper, David the Prophet in Sa'adya Gaon's Commentary on Psalms and its Syriac and Karaite Contexts, Arye Zoref analyzes Sa'adya's Commentary on the Book of Psalms against the backdrop of similar commentaries produced by Christian (in Syriac) and Karaite (in Arabic) exegetes. He argues that in an attempt to stress the unity of the book of Psalms and its prophetic nature, Sa'adya adopted only those concepts from the Syriac commentaries which best suited his purpose, and demonstrates that the Gaon modeled his introduction to the commentary on Psalms on the introductions of two Syriac commentators (Moshe Bar Kepha and Ishodad of Merv), and that he adopted the Syriac Nestorian idea that David wrote all the Psalms, but rejected some of the Nestorian interpretative approaches, such as a general disregard for the Psalms' headings.

In the following chapter, Psalms to Reason, Psalms to Heal. The Scriptures in Early Rūm Orthodox Treatises, Miriam Lindgren Hjälm examines different approaches to Scripture in general, and exegetical uses of the Book of Psalms in particular, in early Rūm Orthodox (Melkite) texts. From this corpus of texts, she singles out general statements relating to Scripture and explains them both in terms of reception of the Patristic heritage and as a message delivered to an audience in a specific context. Another question discussed in the paper relates to the authors' conception of the Hebrew text of the Bible (e.g., Abu Qurra seems unaware that certain biblical books are not canonical among the Jews as well as ignorant of the fact that the Hebrew, Syriac and Greek versions sometimes differ, while Agapius of Manbiğ invests much effort in proving that such deviations were introduced by the Jews for the purpose of obfuscating the notion that the Christ was the Messiah). In addition, the paper investigates the uses of the Psalms' quotations in the analyzed texts. She demonstrates that, most often, Psalms that are understood to be prophetical are chosen to prove Christian doctrines as expressed in the New Testament. By Agapius, however, they are also used to recapitulate events recorded within the Old Testament corpus. Finally she shows how Agathon of Homs, makes the most complex use of the Psalms. The conclusion is that the genre of the text dictates the exegetical use of the Psalms.

Among the many extant Arabic manuscripts of "the Psalms of David" are some that begin by sounding like translations of the biblical Psalms but turn out, on further investigation, to contain fresh compositions by Muslim authors. Our next author, David R. Vishanoff, in his paper Images of David in Several Muslim 
Rewritings of the Psalms, identifies several different versions of these psalms, each of which starts with a shared core of one hundred psalms and then edits, reorganizes, rewrites, and adds to that core material. It demonstrates that each version presents David in a somewhat different light: although all present him as a model of repentance and otherworldly piety, some emphasize the gravity of his sin and tearful repentance, while others minimize his sin and promote a piety of strict orthodoxy and obedience. In addition, the article shows that each editor uses the shared symbol of David and his Psalms to advance his own vision of Islamic piety, not in opposition to Jewish or Christian pieties, but as a critique of worldliness within the Muslim community.

Among all the Arabic versions of the Book of Psalms produced by Christian translators, one stands out for its unique features. It is a translation of the text of the ${ }_{151}$ Psalms from the Greek original (according to the Septuagint) prepared by the eleventh century Melkite deacon Abū 'l-Fatḥ 'Abd Allāh ibn al-Faḍl ibn 'Abd Allāh al-Muțrān al-Anțākī. The author also added a fine commentary (in Arabic) to his translation. In the chapter David's Psalter in Christian Arabic Dress: 'Abd Allāh ibn al-Faḍl's Translation and Commentary, Juan Pedro Monferrer-Sala offers a description of Ibn al-Faḍl's Arabic translation and commentary on the Psalms, and argues that the importance of this text is confirmed by the existence of numerous revisions of the original Arabic version. In addition, the article includes an edition and analysis of Psalm 28 according to Ms. Sinai Ar. 65 which illustrates the changes to which the original Arabic version was subjected through the various revisions.

In the next paper of this section, King David and the Psalter in Ethiopian Cultural Setting, Witold Witakowski demonstrates that although few compositions in Classical Ethiopic (Gə`əz) are devoted specifically to David, or attributed to him, he is not an insignificant figure in Ethiopian culture and tradition. The paper argues that his importance and popularity depend on two circumstances: (1) David is regarded to be the author of the biblical Book of Psalms, which in Ethiopia is simply referred to as Dāwit, and whose popularity is based on the fact that the Psalter is used as a primer in traditional schools by which children learned how to read and write; (2) David is connected to the sphere of the cult of Mary as one of her ancestors, sometimes just being called "The Father of Mary." Consequently, he often appears in the texts devoted to Mary, such as the Miracles of Mary. In addition, Witakowski shows that even more impressive testimonies of David's importance can be found in iconographic representations. For instance, the image of David playing bägäna, a traditional Ethiopian stringed instrument, can be found in manuscript illuminations and in wall paintings in various churches. The article offers a synthetic overview 
and analysis of all these diverse sources, which have so-far been unstudied or understudied.

The Book of Psalms has always played an important role in the life of Eastern European Karaites, who had been using the Hebrew Psalms in liturgy held in the prayer houses called kenesa. At the turn of the nineteenth and the beginning of the twentieth centuries, the language of liturgy changed from Hebrew to the Turkic vernacular of the Eastern European Karaites (so-called Karaim language). At about the same time, new Latin and Cyrillic based orthographies were introduced, and started to gradually replace the previously used Hebrew orthography. In the paper David's Psalms in Eastern European Karaite Literature, Zsuzsanna Olach investigates how these processes, together with the "emancipation" of the Eastern European Karaites, brought about the emergence of Eastern European Karaite Bible translations, including translations of the Book of Psalms, both in old Hebrew script and in new orthographies. She argues that the significance of the Psalms among the Eastern European Karaites goes far beyond the liturgical context, demonstrating that individual Psalms have been adapted into hymns and religious poems by Karaim poets (e.g., Zarax ben Natan and Josef ben Shemuel), while singular verses and stanzas from the Psalms were profusely quoted in their poetical compositions. The article discusses various adaptations of individual psalms into poems offered by Karaim poets, offering the first results of a study of the use of the Book of Psalms in Eastern European Karaite literature.

\subsection{David and His Women:The Cross-Religious Reception Exegesis of the Bathsheba Narrative}

The Bible did not emerge in a cultural vacuum. Rather it bears witness to the fruitful cultural encounters between the ancient Jewish and the surrounding non-Jewish cultures, most notably the Greek/Hellenistic one. In the first chapter of this section, The Four Wives of David and the Four Women of Odysseus: $A$ Comparative Approach, Daniel Bodi offers a literary analysis which juxtaposes the female biblical characters of Michal, Abigail, Bathsheba and Abishag, with those of the Greek epic, Odyssey: Calypso, Circe, Nausicaa and Penelope. It demonstrates that the Hebrew Bible places women at significant moments in David's career - from a young humble warrior to a seasoned warlord and an aging ruler - which is comparable to the role played by women in the career of Odysseus from his ten-year absence from his island Ithaca for the duration of the Trojan war and his additional decade-long return voyage home to his faithful wife Penelope. The paper argues that all these female figures (symbolically representing the four types of women a man can meet in his life), who 
played a crucial role in the lives of David and Odysseus, act as reflecting mirrors, bringing to the fore different aspects of David and Odysseus' personalities and, allowing both characters to acquire a truer perception of themselves, their limits and shortcomings. In addition, Bodi points to the existence of other similarities between the analyzed narratives: Both Odysseus and David are major cultural heroes who are the main characters of the stories associated with them. Both the Homeric Epic and the biblical story of David offer fine observations on human nature. Both cultural heroes are depicted as being in need of the help of women in order to advance their lives and careers. In both cases, weakness or failure occurs because of their impulsive, heroic temperament - a traditional theme.

Yet, the Bible has always inspired interest not only as literature, but also and perhaps above all - as a historical document. From the exegetical point of view, one of the most problematic episodes in the biblical narrative on David is his affair with Bathsheba (2 Samuel 11:1-12:25). Many questions arise from this remarkable story: How is David evaluated by the biblical narrator? What was Bathsheba's part in this affair? Why did Uriah not go to his house as ordered by David? Did he know of David and Bathsheba's affair? Why did Nathan choose to convey the divine message through a parable, rather than convict David directly? Why was David punished for his sin in a different way than Saul? In the chapter, Josephus' Retelling of the David and Bathsheba Narrative, Michael Avioz focuses on the way in which the ancient Jewish historian addressed these questions and rewrote the David-Bathsheba narrative. He discusses the subject against the backdrop of the biblical text and its traditional rabbinic interpretations, and demonstrates that although it posed a great challenge to Josephus' generally positive view of King David and despite the fact that he could have followed the Chronicler's account and omitted this episode, the author of the Antiquities of the Jews decided to retain most of the problematic source material (with minor changes) and to confront it head-on. Avioz uncovers Josephus' techniques when rewriting this narrative and tries to understand the reasons behind the changes he introduced (as influenced by Greek culture and its values, such as piety, justice, courage, obedience).

The next, panoramic article by Diana Lipton and Meira Polliack, Our Mother, Our Queen: Bathsheba through Early Jewish, Christian and Muslim Eyes, considers the complex portrayals of David and Bathsheba in the three religions which, in different ways, see themselves as David's heirs. In a story about succession and inheritance, Bathsheba appears at first to be a cartoon character in a cautionary tale about the dangers that beautiful women pose to powerful men. But, eventually, Bathsheba turns out to be pivotal in the so-called "succession narrative"; her son, Solomon, is David's heir. Lipton and Polliack analyze 
a representative selection of textual and visual sources, mainly - though not uniquely - medieval, in an attempt to better understand Jewish, Christian and Islamic exegetical approaches - internal and in relation to each other - to dealing with complications in the Davidic lineage.

Ancient Christian Bible exegesis has much in common with rabbinic interpretations, largely due to the common use of the Hebrew Bible/Old Testament. This is true in the Syriac literature even more so than in the Greek and Latin works. Syriac Christian writings contain many exegetical points that appear to have been influenced by rabbinic Judaism. At the same time, the Syriac-speaking church had been in constant conflict with Judaism since Syriac literature first emerged in the late third century, and consolidated in the fourth century. In the next chapter, God's Master Plan: The Story of David and Bathsheba in Some Early Syriac Commentaries, Orly Mizrachi argues that all this is reflected in the Syrian exegesis of 2 Samuel 11-12. So, for instance, David is perceived as a prefiguration of Christ and his repentance is perceived as characteristic of His future era, when the biblical law will be annulled and the most important act of the Christian believer will be repentance. The paper demonstrates that during the Christological controversy in the fifth and in the sixth centuries, two independent Syriac-speaking churches were established. Thus, the biblical commentaries on these chapters are also a source of information concerning an internal dialogue between Jacob of Edessa and his predecessors in the Syrian Orthodox Church, on the one hand, and Ishodad of Merv and those who preceded him in the Church of the East, on the other.

In the last article of this section, Ibn Katīir's (d.774/1373) Treatment of the David and Uriah Narrative: The Issue of Isrä'iliyyāt and the Syrian School of Exegesis, Marianna Klar demonstrates that Ibn Katīr's treatment of the David and Uriah narrative, held by many to underpin the qurānic pericope at Sura 38:21-25, is tantalizingly brief. Indeed, the visible tip of his act of exegesis consists merely of a two-pronged dismissal of "the story that the exegetes relate," a gloss of the qur'annic vocabulary, and an aphorism: "the good deeds of the pious are the bad deeds of [God's] intimates." The paper argues that underlying this, however, is a sizeable degree of unspoken scholarly interaction between Ibn Katīir and the works of his peers. It demonstrates that Ibn Katiir may rarely cite later exegetes by name, but he appears to have engaged substantially with their works, and indeed to have assumed his scholarly audience to be as familiar with their main points and their principal arguments as he was. It posits the existence of a specifically Syrian school of exegesis, whose parameters influenced Ibn Katiir much more profoundly than has previously been acknowledged: the importance of al-Hāzin al-Bağdādī, in particular, would appear to have been critically overlooked. Finally, it postulates that Ibn Katīir's usage of the term isrä̀iliyyāt 
should meanwhile be viewed within a much wider discussion of contemporary attitudes towards inherited exegetical material in general.

\subsection{Reinventing David in Early Modern and Modern Religious Thought and Literature}

The first chapter of this section brings us to eighteenth century Poland and the fascinating figure of Jacob Frank (1726-1791), a Polish-Jewish religious leader who claimed to be the reincarnation of the biblical patriarch Jacob and of the self-proclaimed messiah Sabbatai Zevi. Frank arguably created a new religious movement, later called Frankism, which combined some aspects of Judaism and Christianity. In the chapter, "David Was Secretly a Woman": King David as a Messianic Topos in the Teaching of Jacob Frank, Jan Doktór explores the reception of King David and the shaping of his image in the teaching of Jacob Frank. The article investigates the reason why the figure of David caught Frank's attention, despite his having pointedly abandoned the traditional messianic idea of returning to the Holy Land and the restoration of the kingdom of David. In addition, it addresses the question concerning which of David's "messianic attributes" Frank wished to imitate and why, and demonstrates that Frank viewed David as "secretly a woman" (an incarnation of the Shekhinah [Heb. Šekina a]). Accordingly, in his opinion, it was David's femininity that endowed him with salvific skills. Finally, the paper delves more deeply into the question of how this Davidic femininity should be understood - whether, in a literal sense, he was a woman, or whether a feminine aspect of divinity manifested itself in his person - and deals with Frank's progressive idea that the arrival of the messianic era will put an end to gender segregation.

The next paper by Elżbieta Lazarewicz-Wyrzykowska, Davidic Narratives in the Contemporary Roman Catholic Liturgical Readings, examines the passages from Davidic narratives in the books of Samuel and 1 Kings included in the contemporary Roman Catholic breviary and lectionary as "readings," in light of the Christological focus of these liturgical collections. It argues that the decision about the inclusion of these passages in spite of the complex and potentially problematic image of David they convey was influenced by a number of interpretative traditions. This includes both the praise of David in Sirach 47:211, easily yielding itself to generally Christian and specifically Catholic exegesis, and the Christian reception of David in the Gospel passion narratives, as well as later exegetical traditions, i.e., medieval monastic teachings of Aelred of Rievaulx and thirteenth century Dominican homiletics. The article explores also the means employed by the compilers of the liturgical collections to harmonize the selected biblical passages with these traditions.

Finally, in the last chapter, The Reception of David and Michal in Twentieth and Twenty-First-Century Literature, Sophia Lena Tiemeyer analyses the way in 
which four selected twentieth century novels function as midrash, understood in its broad sense as literature which interacts with and interprets the biblical material. The paper focuses on the novelists' interpretations of the relationship between David and Michal. The biblical narrative offers but a brief description of their interaction, yet these sparse references encourage readers to explore further their respective feelings for each other and the motives behind their actions. The article is centered around a set of questions, originally posed by David Clines vis-à-vis the biblical narrative. (1) Why does David marry Michal, given that Saul initially offered his elder daughter Merab as a reward? (2) Why does Michal love David? (3) Does David love Michal back? (4) How should Michal's position between her husband David and her father Saul be understood? (5) How should the presence of the terapim in David's and Michal's bedroom be understood? (6) What does Michal feel about her husband Paltiel? (7) Why does Michal reproach David when he dances in front of the Ark of the Covenant? In addition, Tiemeyer addresses the following questions: What answers do these select novels offer and how do their modern perspectives influence their readings of the ancient tale? She argues that all the novels base their readings on existing narrative gaps in the text which they, in turn, seek to fill. The biblical story is ambiguous and this ambiguity paves the way for a wide range of interpretations. Thus, in a broad sense, these novels offer valuable interpretations of the biblical Davidic narrative.

We believe that the collection of chapters included in the present volume will contribute to our understanding of how different religious traditions accommodated one another and shaped their respective boundaries through the process of an ongoing, intensive and extensive dialogue over their sanctified texts. Its main beneficiaries will be scholars and students of Jewish, Christian and Islamic studies, especially those interested in Bible and Qurān exegesis and other religious literature, but also scholars of comparative literature and literary theory, historians, historians of art, cultural scientists and possibly also sociologists. Yet, we hope too that the book will offer something of interest to a wider public which will also benefit from its results, given the socio-historical importance of interreligious relations and the impact that these religious traditions had on the development of human culture and civilization as a whole.

Far from offering a comprehensive account of the reception history of King David and the Psalms in all monotheistic traditions throughout the ages, the volume intends to illustrate the diversity and richness of the process of cross-cultural interchanges among Jews, Christians and Muslims, especially 
in the Middle Ages, as exemplified in their perceptions and receptions of this central biblical figure and his attributed book, recognized in all monotheistic traditions as a sacred text. Accordingly, it contributes to our understanding of the multilaterally fertilizing effect that these interchanges had upon the major monotheistic religious traditions, their cultures and literatures, helping us to recalibrate and reassess the nature of the complex, enduring relationship between Judaism, Christianity and Islam, and to reconstruct the trajectories of cross-cultural contacts and transfers of ideas between them.

\section{Technical Comments}

Jewish, Christian and Islamic studies are generally considered to be independent academic disciplines and often studied and researched separately. So are different Semitic languages (e.g., Hebrew, Aramaic, Arabic, Syriac, Classical Ethiopic [Gə๖əz]), Classical languages (Latin and Greek), and Slavic languages (e.g., Polish), which traditionally belong to different university departments. Investigating source texts written in all the above-mentioned languages by representatives of different religious traditions, and combining papers written by scholars of different academic backgrounds which represent a variety of academic disciplines and approaches, the present volume has a pronounced interdisciplinary and interreligious character. Therefore we decided to provide Latin transcription of all words written in non-Latin characters in the main text. For the same reasons, we provide full titles of biblical and other classical books and generally avoid abbreviations which might be intelligible in one discipline, but unknown to researchers representing other scholarly fields (e.g., мт for Masoretic text, or LXX for the Septuagint). We also try and explain all specialized terminology.

Except for quotations from other works, proper names (such as Rashi) and lexicalized words or terms that infiltrated English academic discourse (e.g., Shi'ism), we use scientific transliteration (see pp. xiii-xiv) throughout the volume. In addition, unless indicated otherwise, the dates are provided according to the common era (CE), albeit they may occasionally be accompanied by dates in the Muslim and Jewish calendars.

The book was partially edited and prepared for publication within the framework of the research project Hebrajska poezja ztotego wieku wal-Andalus. Antologia [The Hebrew Poetry of the Golden Age in al-Andalus. An Anthology] sponsored by the National Program for the Development of Humanities (NPRH; grant Uniwersalia 2.2) awarded to Dr. Marzena Zawanowska (20182O23; No. 22H/18/0199/86). 
Most of the authors of the papers included in this volume presented drafts of their chapters at the international conference Warrior, Poet, Prophet and King: The Character of David in Judaism, Christianity and Islam, hosted by the Institute of History, University of Warsaw and the Emanuel Ringelblum Jewish Historical Institute in Warsaw in October, 2016, and generously sponsored by the European Association for Jewish Studies (EAJS) Conference Grant Programme in European Jewish Studies. ${ }^{5}$ It was organized by Mateusz Wilk (University of Warsaw) and myself, while Camilla Adang (Tel Aviv University), Juan Pedro Monferrer-Sala (University of Córdoba), Łukasz Niesiołowski-Spanò (University of Warsaw), and Meira Polliack (Tel Aviv University) formed the scientific advisory board of the event. I would like to thank them wholeheartedly for their wise advice, patient support and organizational collaboration.

I should also like to convey my deepest gratitude to all the contributors of the present volume, without whom this work would have never seen the daylight, and especially to my colleague and dear friend, Prof. Meira Polliack who not only contributed - together with Dr. Diana Lipton - an excellent paper to the volume, but also has generously devoted her time to discuss various aspects of this project with me and suggested significant improvements to the draft of this introduction. In addition, I wish to thank Mr. Hugh Doyle for reading a final version of this volume and suggesting certain corrections and Dr. Magdalena Bendowska for helping us to choose the cover illustration. Together with Mateusz Wilk, we also owe a debt of gratitude to Mr. Jorik Groen from Brill who showed unusual kindness in patiently assisting us during the final stages of preparing the book for printing. My special thanks go to Prof. Łukasz Niesiołowski-Spanò and Prof. Paweł Śpiewak for having enabled me to pursue my academic career and supported in many different ways. Finally, I would like to thank my family - my ever supportive husband and friend, Marcin, as well as my two beloved kids, Ada and Krzyś, for their patience with their often absent-minded wife and mother.

\section{Bibliography}

Akhiezer, Golda. Historical Consciousness, Haskalah and Nationalism of Eastern European Karaites. Jerusalem: Ben-Zvi Institute for Study of Jewish Communities in the East, 2016 [in Hebrew]. Translated into English by David B. Greenberg. Leiden Boston: Brill 2018.

5 See Zawanowska, "Warrior, Poet, Prophet, and King." 
Astren, Fred. Karaite Judaism and Historical Understanding. Columbia, SC: University of South Carolina Press, 2004.

Ben-Shammai, Haggai, "The Karaite Controversy: Scripture and Tradition in Early Karaism." In Religionsgespräche im Mittelalter, edited by Bernard Lewis and Friedrich Niewöhner, 11-26 [Wolfenbütteler Mittelalter-Studien, vol. 4]. Wiesbaden: Harrassowitz, 1992.

Ben-Shammai, Haggai, "Return to Scriptures in Ancient and Medieval Jewish Sectarianism and in Early Islam." In Les retours aux Ecritures. Fondamentalismes présents et passés, edited by Evelyne Patlagean and Alain Le Boulluec, 319-339. Louvain - Paris: Peeters, 1993.

Cook, Michael. "Anan and Islam: The Origins of Karaite Scripturalism." Jerusalem Studies in Arabic and Islam, 9 (1987): 161-182.

Drory, Rina. The Emergence of Jewish-Arabic Literary Contacts at the Beginning of the Tenth Century [in Hebrew]. Tel Aviv: Porter Institute of Poetics and Semiotics, 1988.

Franklin, Arnold E. This Noble House Jewish Descendants of King David in the Medieval Islamic East. Philadelphia: University of Pennsylvania Press, 2013.

Gil, Moshe. "Karaite Antiquities" [in Hebrew]. Te uda, 15 (1999), 71-107.

Gil, Moshe. "The Origins of the Karaites," in Karaite Judaism: A Guide to its History and Literary Sources, edited by Meira Polliack, 73-118. Leiden: Brill, 2003.

Moss, Yonatan. From David to Davids: An Abrahamic Onomastic Revolution, paper presented at the international conference "Warrior, Poet, Prophet and King: The character of David in Judaism, Christianity and Islam," organized and hosted by the Institute of History, University of Warsaw, in cooperation with the Emanuel Ringelblum Jewish Historical Institute in Warsaw (Warsaw, 26-28 October, 2016).

Polliack, Meira, "Conceptualization of the Biblical Story and its Crystallization from Oral Sources in Writing: On Innovations of Judaeo-Arabic Interpretations in the Middle Ages" [in Hebrew]. In Bein Ever Le-Arav, edited by Yosef Tobi, vol. 6, 109-152. Tel Aviv: Ofakim, 2014.

Polliack, Meira. "The Karaite Inversion of »Written« and »Oral« Torah in Relation to the Islamic Arch-Models of Qur'an and Hadith." Jewish Studies Quarterly 22 (2015): 243-302.

Zawanowska, Marzena. "Warrior, Poet, Prophet, and King: The Character of David in Judaism, Christianity, and Islam (Warsaw, 26-28 October 2016)." Collectanea Christiana Orientalia, 14 (2017), 219-241.

Zawanowska, Marzena. "Warrior, Poet, Prophet, and King: The Character of David in Judaism, Christianity, and Islam. Academic report on international conference organized and hosted by the Institute of History, University of Warsaw, in cooperation with the Emanuel Ringelblum Jewish Historical Institute in Warsaw, sponsored by the European Association for Jewish Studies (EAJS) Conference Grant Programme in European Jewish Studies (Warsaw, 26-28 October, 2016)." Kwartalnik Historii Żydów - Jewish History Quarterly, 1(261) (2017), 153-166. 